\title{
Agricultural Land Utilization Efficiency: The Case of Latvia
}

\author{
I. Pilvere, A. Nipers, and I. Upite
}

\begin{abstract}
Agricultural land is critically important, but limited resource for production of agricultural goods. Therefore, it is essential to exploit agricultural land efficiently to provide the planet's growing population with food. We evaluated how efficient is utilization of the agricultural land in a northern country called Latvia. Based on statistical data at micro level, we evaluated inefficiently exploited areas that potentially might be available for the production of agricultural products. It is discovered that in 2013 as much as $37 \%$ (or 874.4 thousand hectares) of utilized agricultural area were not efficiently exploited in the country. The reasons for ineffective use are described and production potential is evaluated.
\end{abstract}

Index Terms-Agricultural land utilization, land availability, efficiency.

\section{INTRODUCTION}

As scientists Achim Dobermann and Rebecca Nelson [1] pointed out, agriculture is the world's largest use of land, occupying about $38 \%$ of the Earth's terrestrial surface. The Food and Agriculture Organization (FAO) of the United Nations [2] emphasise that for rural women and men, land is perhaps the most important household asset to support production and provide for food, nutrition and income security. The European Commission [3] points out that agriculture depends on the use of natural resources such as land, soil, water, and nutrients. In an economy, land is one of the most important factors of production along with entrepreneurial ability, information, labour, and capital [4], which, if rationally exploited, maintain fertility, and it may be also exploited by future generations. Agricultural land is an important resource in the economy of Latvia, as in Latvia $98 \%$ of land is situated in the countryside. From the total area in Latvia, woodland comprises $46 \%$ of this area, but $38 \%$ is agricultural land [5]. In the European Union (EU), Latvia may be regarded as a country rich in natural capital. Latvia's population density is relatively low, therefore, the country is one of the "greenest" and least-urbanised EU territories. Latvia's largest natural endowments are forests, soil, some mineral deposits, and water as well as flora and fauna [6].

In the world, scientists much discuss about how to more efficiently exploit resources, including land, to provide the planet's population with necessary food. The agricultural

Manuscript received September 6, 2013; revised October 31, 2013.

I. Pilvere is with the Latvia University of Agriculture, Faculty of Economics and Social Sciences, Latvia (e-mail: ipilvere@gmail.com).

A. Nipers is with the Latvia University of Agriculture, Institute of Economics and Business in Riga, Latvia.

I. Upite is with the Latvia University of Agriculture, Faculty of Economics and Social Sciences, Department of Business and Management, Latvia. community has had tremendous successes in massively increasing world food production over the past five decades and making food more affordable for the majority of the world's population, despite a doubling in population [1]. Yet, according to J. N. Pretty, J. Thompson and F. Hinchcliffe [7] as the previous century drew to a close, agricultural development faced some unprecedented challenges. By the year 2020 , the world will have to support some 8.4 billion people. Even though enough food is produced in aggregate to feed everyone, some 800 million people still do not have access to sufficient food.

Continuing population and consumption growth will mean that the global demand for food will increase for at least another 40 years. But the world can produce more food and can ensure that it is used more efficiently and equitably [8]. Investing in agriculture is also one of the most effective strategies for achieving critical post-2015 development goals related to poverty and hunger, nutrition and health, education, economic and social growth, peace and security, and preserving the world's environment [1].

Richard Flavell [9] stresses that ... we need to increase the rate of gain in food production and .... intensify food production on less land and free up land for other needs. This means working rapidly and purposefully towards intensifying agriculture sustainably to produce the amounts and diversity of food needed using as little land as possible. May the farmers, knowledge generators and entrepreneurs of the world teach us all, and especially disconnected decision-makers and citizens, how to overcome our current challenges, decade by decade and create the sustainable promised land for 9 billion people [9].

Sustainable intensification of agriculture is known to offer significant opportunities to improve food production. Sustainable intensification is a term now much used in discussions around the future of agriculture and food security. On the one hand, scientists T. Garnett and C. Godfray [10] emphasise that sustainable intensification is not wedded to any one agricultural approach. It is based upon the principle that in a complex world with a growing population, the more effective use of inputs and the reduction of undesirable outputs in order to achieve greater yields - intensification - is fundamentally required in order to achieve sustainability. A similar opinion belongs to J. N. Pretty, J. Thompson and F. Hinchcliffe [7], who point out that the basic challenge for sustainable agriculture is to make better use of available biophysical and human resources. This can be done by minimising the use of external inputs, by optimising the use of internal resources, or by combinations of both.

One of the opportunities is to support national policies and strategies for sustainable agriculture. However, a critical 
debate and dialogue is essential to move forward with the alternative agriculture movement, especially if the goal is to promote a truly alternative agricultural path [11]. FAO [2] stresses that sound policies are needed to create the incentives and capacities for sustainable consumption and production and to enable consumers and producers to make sustainable choices.

In Latvia, the problems of land utilisation have been researched by many scientists - A. Dobele [4], V. Baumane [12] and [13], A. Lenerts un I. Pilvere [14], A. Dobele, I. Pilvere, E. Ozols, L. Dobele [15], I. Pilvere [16] and others. Foreign scientists point out that sustainable intensification has been focused on developing countries, where the imperative for output increases are paramount. Fewer studies have applied the concept to developed economies. A.P. Barnes and C. E. Z. Poole [17] emphasise that a number of influential policy circles have championed the concept of sustainable intensification as a technology to meet the challenge of a growing population. Various definitions exist for sustainable intensification, but the concept is driven by future constraints on land use.

In Latvia, the inefficient exploitation and excess of land are regarded as problems, whereas in other EU countries there are discussions about the lack of land [18]. That is why a hypothesis is defined in the present research as follows: it is possible to increase the exploitation efficiency of utilised agricultural area (UAA) in Latvia that could be used for agricultural production in the future.

To prove or reject the hypothesis, it is necessary to assess Latvia's land resources exploited in agriculture and whether it is possible to exploit them more efficiently in order to contribute to the worlds' food security, maintaining the sustainability of land resources.

Research object: utilised agricultural area.

Research aim: to assess the resources of agricultural land in Latvia in order to determine the possibilities for their intensive and effective use in agricultural production in the future.

In order to reach the research aim, the following research tasks have been set:

1) To determine the resources of UAA in Latvia in various groups of use.

2) To assess the availability of inefficiently exploited agricultural land for agricultural production in Latvia.

3) To estimate the output of agricultural products for the improved exploitation of UAA.

Research methodology and methods - several research methods were used. In order to determine UAA resources and their quality, as well as to estimate the output of agricultural products, were used constructive calculation method, the statistical analysis method, as well as data grouping method. Data grouping was performed by using the MS Excel tool Data Filter. The monographic method, the document analysis method, analysis and synthesis methods were used to describe and represent the research results. The research analysed information from the State Land Service (SLS) and the Rural Support Service (RSS) databases and statistical data from Eurostat. In the study design process, special and general literatures in relation to the topic of research were used.

\section{ASSESSMENT OF THE EXPLOITATION OF UAA IN LATVIA}

In 2011 in Latvia, the UAA occupied $37.6 \%$ of the country's total territory, which was a $1.7 \%$ decrease compared with 2005 [12]. Land resources can ensure the country's food security. Yet, large areas of agricultural land are not exploited for agricultural purposes and gradually overgrow, degrading the surrounding environment. The reason for it is the large number of farms that are not practically able to compete in producing traditional agricultural products [6]. There were more than 83 thousand farms in Latvia in 2010, and the average UAA per farm was 19.6 hectares [19] and [20]. Besides, only approximately $45 \%$ of the total number of farms in Latvia produces agricultural goods for sales in the market [21]. The European Commission's opinion has to be taken into consideration that smallholder farms are an important part of the solution and they must be supported to achieve productivity gains [3]. Therefore, in Table I, the uses of UAA by category in Latvia are summarised:

- $\quad$ Productive areas are arable land, fallows, plantations of perennial grasses, perennial fruit-trees, nectar plants, short-rotation coppice species (aspen, osier, grey alder with a 5-year harvest cycle), and permanent meadows and pastures used for raising livestock;

- Areas declared for the Single Area Payment Scheme (SAPS), which are maintained in good agricultural and environmental condition;

- The RSS uses the Field Register's geographical information system (GIS) information on agricultural land in the form of agricultural parcels. The agricultural parcels are the UAA that was maintained in good agricultural condition as of 30 June 2003 and the area of which is equal or less than 0.30 ha and which border on the boundaries of stable objects identifiable in nature;

- The SLS classifies the land whose purpose of use is defined as "agricultural" into two types: land for agriculture as the main economic activity and land for crops, moving grass, grazing livestock, growing feed crops, orchards, and other perennial fruit-trees, vegetable gardening, floriculture, fungiculture, and crops under glass;

- $\quad$ Since 2004, the Latvian State Forest Research Institute (LSFRI) "Silava" has been surveying the entire territory of Latvia, thus collecting statistical information on land resources.

TABLE I: DISTRIBUTION OF THE UAA BY CATEGORY IN LATVIA IN 2010 AND

\begin{tabular}{|c|c|c|c|c|}
\hline \multirow{3}{*}{$\begin{array}{l}\text { Distribution of } \\
\text { the area }\end{array}$} & \multicolumn{2}{|c|}{2013} & \multirow{2}{*}{\multicolumn{2}{|c|}{$\begin{array}{l}\text { Change from the } \\
\text { base year }\end{array}$}} \\
\hline & \multirow[t]{2}{*}{2010 (ha) } & \multirow[t]{2}{*}{2013 (ha) } & & \\
\hline & & & ha & index \\
\hline Productive area & 1368000 & 1459051 & 91051 & 107 \\
\hline Area declared & & & & \\
\hline for the SAPS & 1566000 & 1638574 & 72574 & 105 \\
\hline $\begin{array}{l}\text { Area of the } \\
\text { agricultural }\end{array}$ & & & & \\
\hline parcels & 2162000 & 2038986 & -123014 & 94 \\
\hline UAA,SLS data & 2430000 & 2386574 & -43426 & 98 \\
\hline UAA, LSFRI & & & & \\
\hline Silava" data & 2369000 & 2191070 & -177930 & 92 \\
\hline
\end{tabular}

Source: RSS, SLS, LSFRI “Silava” data bases, 2013 [22], [23] and [24]

A comparison of the productive area and the area declared or the SAPS (Table I) shows that there were 5-7\% increases in these areas in Latvia in the period 2010-2013, yet, the total 
potential resources of agricultural land, for their use in the future, decreased within a range of $2-8 \%$, depending on the data source.

To determine the potential of exploitation of UAA in the future, it is necessary to analyse the distribution of UAA by size (Table II).

The analysis of the RSS Field Register's GIS information leads to a conclusion that agricultural holdings occupying from $31 \%$ (productive area) to $36 \%$ (agricultural parcel area) of the total UAA are small and fragmented - less than 20 ha in size - in which raising productivity is difficult. Nevertheless, $63-69 \%$ of the total UAA consists of relatively large holdings in which it would be possible to increase the indicators of land exploitation.

TABLE II: DISTRIBUTION OF THE UAA BY SIZE GROUP IN LATVIA IN 2013

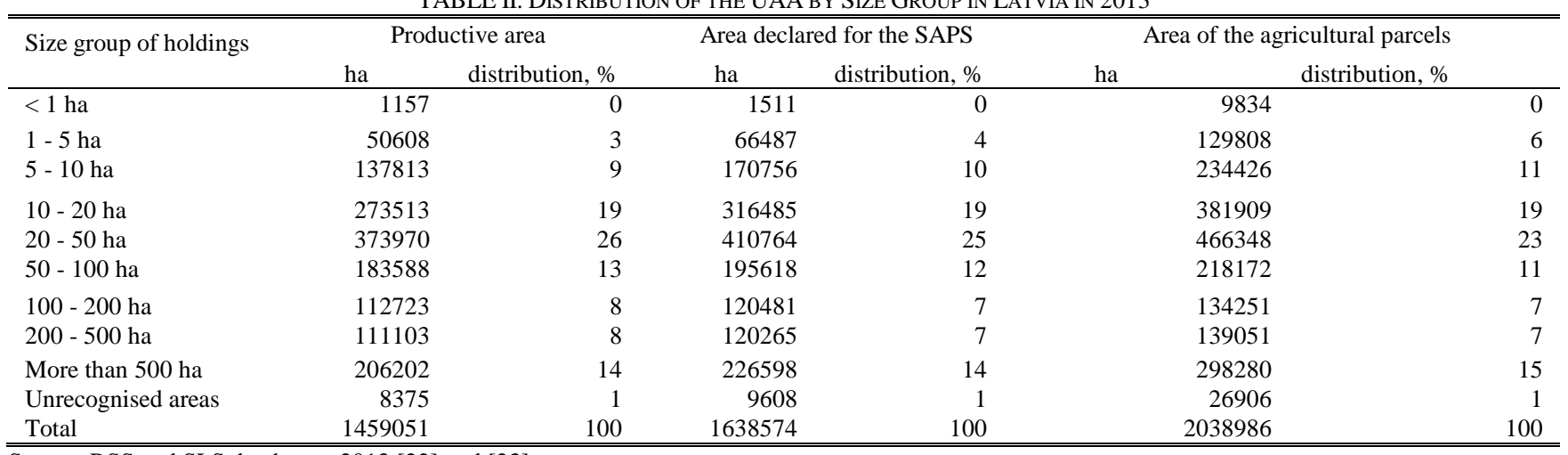

Source: RSS and SLS databases, 2013 [22] and [23]

The quality of UAA has to be taken into account, for instance, the proportion of ameliorated area in the total UAA and agricultural land qualitative estimates in points, as it indicates the suitability of these areas for agricultural production.
Since soil moisture is high in Latvia, it is important whether a particular agricultural parcel is ameliorated. The characteristics of the relatively intensively exploited UAA, broken down by whether it is ameliorated, are presented in Table III.

TABLE III: DiSTRIBUTION OF THE UAA BY SIZE GROUP AND BY WHETHER IT IS AMELIORATED IN LATVIA IN 2012

\begin{tabular}{|c|c|c|c|c|c|c|}
\hline \multirow[b]{2}{*}{ Size group of holdings } & \multicolumn{3}{|c|}{ Productive area, ha } & \multicolumn{3}{|c|}{ Area declared for the SAPS, ha } \\
\hline & ameliorated & unameliorated & unameliorated,\% & ameliorated & unameliorated & unameliorated, \% \\
\hline$<1$ ha & 1424 & 638 & 31.0 & 1673 & 878 & 34.4 \\
\hline $1-5$ ha & 48884 & 13205 & 21.3 & 57965 & 18168 & 23.9 \\
\hline $5-10$ ha & 109596 & 29092 & 21.0 & 126613 & 38595 & 23.4 \\
\hline $10-20$ ha & 253480 & 57508 & 18.5 & 283259 & 72953 & 20.5 \\
\hline $20-50$ ha & 420147 & 82321 & 16.4 & 455736 & 100159 & 18.0 \\
\hline $50-100$ ha & 231591 & 36165 & 13.5 & 247404 & 42823 & 14.8 \\
\hline 100 - 200 ha & 96204 & 14919 & 13.4 & 104693 & 19670 & 15.8 \\
\hline $200-500$ ha & 41185 & 4607 & 10.1 & 42895 & 5184 & 10.8 \\
\hline More than 500 ha & 12984 & 1256 & 8.8 & 13662 & 1779 & 11.5 \\
\hline Unrecognised areas & 3024 & 822 & 21.4 & 3372 & 1093 & 24.5 \\
\hline Total & 1218518 & 240533 & 16.5 & 1337272 & 301303 & 18.4 \\
\hline
\end{tabular}

Source: RSS and SLS databases, 2013 [22] and [23]

According to the RSS Field Register database, the proportion of ameliorated area on small agricultural holdings with the size of less than 20 ha is lower, but the greater is the size of an agricultural holding, the relatively greater is its ameliorated area; on average in the country, $84 \%$ of the productive area and $82 \%$ of the area declared for the SAPS are ameliorated.

A similar situation is observed regarding UAA qualitative estimates $-19 \%$ of small holdings (less than 20 ha) and $12 \%$ of larger holdings (more than 20 ha) are estimated below 25 points (average in Latvia is 38 points), which, according to experienced agronomists, is insufficient in Latvia to exploit this area for agricultural production, as too large investments are necessary for it [24].

\section{ASSESSMENT OF THE INEFFICIENTLY EXPLOITED AGRICULTURAL AREA IN LATVIA}

To identify the inefficiently exploited agricultural area in
Latvia, the following calculations were performed (Table IV)

- $\quad$ The mowed area, which was only mowed once a year and thus contributed to the formation of nice rural landscapes but on which no agricultural production took place, was calculated. It was a difference between the area declared for the SAPS and the productive area;

- The area undeclared for the SAPS, which indicated that the owners of these holdings, for some reasons, did not apply for support payments, was calculated; it was a difference between the area of agricultural parcels and the area declared for the SAPS. There might be several reasons for it - the land was not maintained in good agricultural condition as of 30 June 2003, as its owners

- Did not wish inspections to be done on their farm or were not aware of the eligibility criteria for direct payments. Thus, one may make an assumption that the owners of these holdings were not active farmers engaged in intensive agricultural production and, most 
likely, these areas also contributed to maintaining the surrounding landscape;

- The unfarmed agricultural area, which was made up of the difference between the area registered by the SLS and the area of agricultural parcels, was calculated.

Even though the inefficiently exploited agricultural area decreased in Latvia in the period 2010-2013, yet, 37\% of the UAA registered with the SLS are still exploited inefficiently. Of the total inefficiently exploited agricultural area, 66\% contribute to creating "public goods" in rural territories, thereby shaping tidy and attractive landscapes, whereas $34 \%$ are unfarmed and overgrown lands that may not be exploited without making large investments in agricultural production, but they may be used for other purposes, for instance, in forestry.

To assess the availability of inefficiently exploited land for agricultural production in the future, calculations on the distribution of this area by size group were performed (Table $\mathrm{V})$.

\begin{tabular}{|c|c|c|c|c|}
\hline \multirow[t]{2}{*}{ Distribution of the area } & \multirow[t]{2}{*}{$\begin{array}{c}2010 \\
\text { (ha) }\end{array}$} & \multirow[t]{2}{*}{$\begin{array}{c}2013 \\
\text { (ha) }\end{array}$} & \multicolumn{2}{|c|}{$\begin{array}{c}\text { Change from the } \\
\text { base year }\end{array}$} \\
\hline & & & ha & index \\
\hline Mowed area & 198000 & 179523 & -18477 & 91 \\
\hline Area undeclared for the SAPS & 596000 & 400412 & -195588 & 67 \\
\hline Unfarmed area & 366403 & 294508 & -71895 & 80 \\
\hline Inefficiently exploited area & 1160403 & 874443 & -285960 & 75 \\
\hline $\begin{array}{l}\text { Proportion of the inefficiently } \\
\text { exploited area, SLS data, \% }\end{array}$ & 48 & 37 & -11 & 77 \\
\hline
\end{tabular}

Source: RSS and SLS data bases, 2013 [22] and [23]

TABLE V: DisTRIBUTION OF THE INEFFICIENTLY EXPLOITED AGRICULTURAL AREA By SIZE GROUP IN LATVIA IN 2013

\begin{tabular}{|c|c|c|c|c|c|c|c|c|}
\hline \multirow{2}{*}{$\begin{array}{l}\text { Size group of } \\
\text { holdings }\end{array}$} & \multicolumn{2}{|c|}{ Mowed area } & \multicolumn{2}{|c|}{$\begin{array}{l}\text { Area undeclared for } \\
\text { the SAPS }\end{array}$} & \multicolumn{2}{|c|}{ Unfarmed area } & \multicolumn{2}{|c|}{$\begin{array}{c}\text { Inefficiently exploited agricultural } \\
\text { area, in total }\end{array}$} \\
\hline & ha & distribution, $\%$ & ha & distribution, $\%$ & ha & distribution, $\%$ & ha & distribution, $\%$ \\
\hline$<1$ ha & 489 & 0.3 & 11647 & 2.9 & 3 & 0.0 & 12139 & 47.0 \\
\hline $1-5$ ha & 14044 & 7.8 & 71568 & 17.9 & 35258 & 12.0 & 120871 & 66.3 \\
\hline $5-10$ ha & 26520 & 14.8 & 66792 & 16.7 & 47697 & 16.2 & 141009 & 51.2 \\
\hline $10-20$ ha & 45225 & 25.2 & 85843 & 21.4 & 68788 & 23.4 & 199855 & 38.7 \\
\hline $20-50$ ha & 53427 & 29.8 & 89743 & 22.4 & 81020 & 27.5 & 224190 & 29.8 \\
\hline $50-100$ ha & 22471 & 12.5 & 36837 & 9.2 & 34725 & 11.8 & 94033 & 24.9 \\
\hline $100-200$ ha & 13240 & 7.4 & 19628 & 4.9 & 19767 & 6.7 & 52636 & 30.7 \\
\hline $200-500$ ha & 2288 & 1.3 & 4647 & 1.2 & 3602 & 1.2 & 10537 & 17.8 \\
\hline More than 500 ha & 1201 & 0.7 & 5302 & 1.3 & 3648 & 1.2 & 10151 & 41.0 \\
\hline $\begin{array}{l}\text { Unrecognised } \\
\text { areas }\end{array}$ & 618 & 0.3 & 8404 & 2.1 & 0 & 0.0 & 9022 & $\mathrm{x}$ \\
\hline Total & 179523 & 100.0 & 400412 & 100.0 & 294508 & 100.0 & 874443 & 36.6 \\
\hline Distribution, $\%$ & $\mathrm{x}$ & 20.5 & $\mathrm{x}$ & 45.8 & $\mathrm{x}$ & 33.7 & $\mathrm{x}$ & 100.0 \\
\hline
\end{tabular}

In 2013 in Latvia, higher proportions of inefficiently exploited agricultural area were observed for small holdings sized less than 20 ha: $51 \%$ of the mowed area, $50 \%$ of the area undeclared for the SAPS, and $46 \%$ of the unfarmed area, which objectively indicated that these areas were not exploited for agricultural production.

The database indicators showed that relatively high proportions of unameliorated area were observed for the inefficiently exploited area among various categories: $34 \%$ of the mowed area, $41 \%$ of the area undeclared for the SAPS, and $52 \%$ of the unfarmed area. A higher proportion of unameliorated area was specific to the small size groups [24].

The distribution of inefficiently exploited land by quality is presented in Table VI.

TABLE VI: DISTRIBUTION OF THE INEFFICIENTLY EXPLOITED AGRICULTURAL AREA BY QUALITY IN LATVIA IN 2013

\begin{tabular}{|c|c|c|c|c|c|c|c|c|c|}
\hline \multirow[b]{2}{*}{ Size group of holdings } & \multicolumn{3}{|c|}{ Mowed area, ha } & \multicolumn{3}{|c|}{ Area undeclared for the SAPS, ha } & \multicolumn{3}{|c|}{ Unfarmed area, ha } \\
\hline & $\begin{array}{l}>26 \\
\text { points }\end{array}$ & $<25$ points & $\begin{array}{l}<25 \\
\text { points, \% }\end{array}$ & $>26$ points & $\begin{array}{l}<25 \\
\text { points }\end{array}$ & $\begin{array}{l}<25 \\
\text { points, \% }\end{array}$ & $>26$ points & $\begin{array}{l}<25 \\
\text { points }\end{array}$ & $\begin{array}{l}<25 \\
\text { points, \% }\end{array}$ \\
\hline$<1$ ha & 314 & 76 & 19.5 & 1626 & 6638 & 80.3 & 2 & 1 & 29.9 \\
\hline $1-5$ ha & 11645 & 2138 & 15.5 & 163 & 143 & 46.6 & 10200 & 25229 & 71.2 \\
\hline $5-10$ ha & 21570 & 4745 & 18.0 & 14500 & 54825 & 79.1 & 15856 & 31939 & 66.8 \\
\hline $10-20$ ha & 36882 & 8149 & 18.1 & 16584 & 51450 & 75.6 & 24583 & 44369 & 64.3 \\
\hline $20-50$ ha & 43567 & 9659 & 18.1 & 21654 & 67378 & 75.7 & 30844 & 50220 & 62.0 \\
\hline $50-100$ ha & 17842 & 4600 & 20.5 & 24129 & 71338 & 74.7 & 14299 & 20470 & 58.9 \\
\hline $100-200$ ha & 9506 & 3633 & 27.6 & 9921 & 29030 & 74.5 & 8752 & 11016 & 55.7 \\
\hline $200-500$ ha & 1569 & 717 & 31.4 & 6742 & 13726 & 67.1 & 1809 & 1942 & 51.8 \\
\hline More than 500 ha & 684 & 398 & 36.8 & 1540 & 3270 & 68.0 & 2910 & 70 & 2.4 \\
\hline Unrecognised areas & 4 & 4 & 52.3 & 3209 & 2546 & 44.2 & - & - & - \\
\hline Total & 143582 & 34119 & 19.2 & 100069 & 300343 & 75.0 & 109253 & 185255 & 62.9 \\
\hline
\end{tabular}

Source: RSS and SLS databases, 2013 [22] and [23] 
Among the various categories of inefficiently exploited land, relatively high proportions were observed for the land areas having low qualitative estimates, especially the area undeclared for the SAPS $-75 \%$ and the unfarmed area $-63 \%$. Yet, of the mowed area, $4 / 5$ had a qualitative estimate of more than 26 points. A low qualitative estimate $(<25$ points $)$ was specific to the groups of small agricultural holdings.

The areas, the use of which in intensive agriculture will be problematic in the future, have to be excluded from the inefficiently exploited area:

- A part of the unfarmed area, based on the results of previous researches - 199787 ha [18];

- The mowed area and the area undeclared for the SAPS totally 346598 ha, including:

1) Agricultural holdings sized less than 1 ha -12136 ha;

2) Agricultural holdings whose qualitative estimate is below 25 points-34119 ha and 300343 ha, respectively [22] and [23].

Therefore, additionally 328058 ha or $37.5 \%$ of the area exploited inefficiently in 2013 are available for intensive agricultural production in Latvia in the future.

\section{Agricultural Production Gains From RaISING THE EFFICIENCY OF USE OF AGRICULTURAL LAND IN LATVIA}

Foreign scientists admit that in the first instance, emphasis should not be placed on agricultural extensification (i.e. bringing more land under production), but on sustainable agricultural intensification. There is no need for agriculture to expand into uncultivated lands, as existing farmlands contain huge potential that is currently being overlooked [7]. Yet, the situation in Latvia is different, and it is possible to increase the output of agricultural products by: 1) intensifying production on the present productive area; 2) exploiting a part of the presently inefficiently exploited agricultural area.

A similar approach is used in researches performed by other scientists, for example, A.Dobermann and R.Nelson [1] point out that a multi-faceted agro-ecological intensification of food production is necessary to 1 ) increase productivity by at least $70 \%$ on existing crop and pasture land; 2) make farming an attractive economic development opportunity for people living in rural areas, particularly smallholder farmers and small to medium entrepreneurs.

Therefore, there were performed calculations (Table VII) on the productivity levels achieved in EU Member States agricultural output and gross value added (GVA) averages in the years 2007-2012 per ha UAA (on average in 2007 and 2010).

Based on productivity levels, the EU Member States may be classified into several groups:

1) Member States with a high agricultural output level and a relatively high GVA per ha of UAA, as well as a high proportion of GVA in agricultural output;

2) Medium agricultural output and GVA per ha of UAA;

3) Very low agricultural output and GVA per ha of UAA in traditional agriculture, which is indicated by the low proportion of GVA in agricultural output.

Unfortunately, the lowest analysed indicators are observed in Latvia compared with the other EU Member States, which implies that it is possible to increase agricultural production intensity in Latvia. Therefore, 3 possible development scenarios were elaborated for the efficient and intensive exploitation of UAA in Latvia:

1) Minimal (scenario 1) - agricultural output, measured per ha UAA, is increased in the productive area up to $75 \%$ of the EU-12 level, and the presently inefficiently exploited area is not additionally engaged into production; it may be achieved in a medium-term (5-7 years) by efficiently exploiting production resources;

2) Optimal (scenario 2) - agricultural output is increased in the productive area up to the EU-12 level, and the presently inefficiently exploited high-quality land is additionally engaged into production; it may be achieved in a period of 8-12 years;

3) Maximal (scenario 3)- agricultural output is increased in the productive area up to the EU-27 level, and the presently inefficiently exploited high-quality land is additionally engaged into production, which may be achieved in along-term (at least 13-20 years).

The calculation results are summarised in Table VIII.

TABLE VII: Average OutPut Value and Gross Value AdDEd IN the EU Members States

\begin{tabular}{|c|c|c|c|c|c|}
\hline Countries & Output & $\begin{array}{l}\text { lue per ha UAA } \\
\text { deviation from the } \\
\text { average in the } \\
\text { EU- } 27, \%\end{array}$ & Gross value & $\begin{array}{l}\text { added per ha UAA } \\
\text { deviation from the } \\
\text { average in the } \\
\text { EU-27, } \%\end{array}$ & $\begin{array}{l}\text { GVA per ha as a } \\
\text { share of output per } \\
\text { ha UAA, } \%\end{array}$ \\
\hline Latvia & 586 & 27 & 159 & 18 & 27 \\
\hline Estonia & 776 & 36 & 287 & 33 & 37 \\
\hline Lithuania & 849 & 39 & 290 & 33 & 34 \\
\hline Bulgaria & 1073 & 50 & 402 & 46 & 37 \\
\hline Slovakia & 1094 & 51 & 245 & 28 & 22 \\
\hline Romania & 1164 & 54 & 515 & 59 & 44 \\
\hline EU12 & 1249 & 58 & 471 & 54 & 38 \\
\hline Czech Republic & 1264 & 58 & 329 & 38 & 26 \\
\hline Ireland & 1327 & 61 & 324 & 37 & 24 \\
\hline Poland & 1394 & 64 & 540 & 62 & 39 \\
\hline Hungary & 1564 & 72 & 529 & 61 & 34 \\
\hline United Kingdom & 1584 & 73 & 556 & 64 & 35 \\
\hline Spain & 1692 & 78 & 923 & 106 & 55 \\
\hline Sweden & 1707 & 79 & 469 & 54 & 27 \\
\hline Portugal & 1764 & 82 & 655 & 75 & 37 \\
\hline Finland & 1904 & 88 & 611 & 70 & 32 \\
\hline Austria & 2152 & 99 & 886 & 102 & 41 \\
\hline
\end{tabular}




\begin{tabular}{|c|c|c|c|c|c|}
\hline EU27 & 2164 & 100 & 872 & 100 & 40 \\
\hline Slovenia & 2374 & 110 & 881 & 101 & 37 \\
\hline France & 2499 & 115 & 1001 & 115 & 40 \\
\hline Luxembourg & 2696 & 125 & 796 & 91 & 30 \\
\hline Greece & 2829 & 131 & 1453 & 167 & 51 \\
\hline Germany & 2915 & 135 & 920 & 106 & 32 \\
\hline Italy & 3602 & 166 & 1952 & 224 & 54 \\
\hline Denmark & 3657 & 169 & 925 & 106 & 25 \\
\hline Cyprus & 5104 & 236 & 2350 & 269 & 46 \\
\hline Belgium & 5582 & 258 & 1651 & 189 & 30 \\
\hline Malta & 11851 & 548 & 5287 & 606 & 45 \\
\hline Netherlands & 12984 & 600 & 4394 & 504 & 34 \\
\hline
\end{tabular}

Source: authors' calculations based on Eurostat, 2013, 2013, 2013 [25], [26] and [27]

TABLE VIII: DEVELOPMENT SCENARIOS FOR THE INTENSIVE AND EFFICIENT EXPLOITATION OF AGRICULTURAL AREA IN LATVIA

\begin{tabular}{|c|c|c|c|c|c|c|}
\hline \multirow[b]{2}{*}{ Groups of area exploited intensively/ Indicators } & \multicolumn{3}{|c|}{ Additional agricultural output, million EUR } & \multicolumn{3}{|c|}{ Additional gross value added, million EUR } \\
\hline & Scenario 1 & Scenario 2 & Scenario 3 & Scenario 1 & Scenario 2 & Scenario 3 \\
\hline Productive area & 725.1 & 967.4 & 2302.4 & 341.4 & 454.7 & 1041.0 \\
\hline Mowed area & 0 & 96.1 & 228.7 & 0 & 45.2 & 103.4 \\
\hline Area undeclared for the SAPS & 0 & 58.6 & 139.5 & 0 & 27.6 & 63.1 \\
\hline Unfarmed area & 0 & 62.8 & 149.5 & 0 & 29.5 & 67.6 \\
\hline Total & 725.1 & 1184.9 & 2820.1 & 341.4 & 557.0 & 1275.0 \\
\hline Increase against the level of 2007-2012, \% & 69.3 & 113.2 & 269.4 & 120.4 & 196.4 & 449.6 \\
\hline
\end{tabular}

Source: authors' calculation

So, at any scenario, an additional $69-269 \%$ increase in agricultural output can be achieved in Latvia compared with the level reached in the period 2007-2012, which leads to a $120-450 \%$ increase in GVA if a more intensive and efficient use of UAA is practised, thereby contributing to providing the world's population with food. Besides, given the low intensity indicators in agriculture, it is possible to produce additional quantities of agricultural products, maintaining the sustainability of land resources.

\section{CONCLUSION}

Land is an important resource in Latvia's economy, as $98 \%$ of land is situated in the countryside. Agricultural land occupies $38 \%$ of Latvia's total area; its efficient exploitation has to be considered an important political objective, as land, according to studies, is the key resource used in producing food in the country.

In Latvia, a part of UAA is not exploited for agricultural production, as there are 83 thousand small agricultural holdings and their agricultural land is fragmented. Therefore, it is important to identify the intensity of use of UAA. Even though the productive agricultural area increased 7\% in 2013 compared with 2010, yet, the area of agricultural parcels decreased by $6 \%$, which indicated that the potential land resources for intensive agricultural production declined.

The analysis of the sizes of agricultural holdings showed that the holdings occupying $31 \%$ of the productive area and $36 \%$ of the agricultural parcel area are small - less than 20 ha. Besides, the proportion of ameliorated area among the small agricultural holdings was lower and their qualitative estimate was also lower, which limited the intensive exploitation of these holdings.

Although the inefficiently exploited area in Latvia decreased in Latvia in the period $2010-2013,37 \%$ or 874.4 thousand ha of the UAA, registered by the SLS, are still exploited inefficiently. Of the total inefficiently exploited agricultural area, 66\% contribute to creating "public goods" in rural territories, thereby shaping tidy and attractive landscapes, whereas $34 \%$ are unfarmed and overgrown lands that may not be exploited without making large investments in agricultural production, but they may be used for other purposes, for instance, in forestry.

Analysing the possibilities of exploiting the UAA in the future based on the 3 scenarios, one can conclude that in Latvia, by intensively and efficiently exploiting the agricultural area, an additional $69-269 \%$ increase in agricultural output can be achieved, compared with the level reached in the period 2007-2012, and an additional 120-450\% increase in GVA - depending on the scenario and the amount of investments in agriculture.

\section{ACKNOWLEDGMENT}

The research, publication, and dissemination of research results were promoted with the support of the JSC "Latvijas valsts mezi", Contract No. 05-15/8/LVM 5.5-5.1_0015_101_13_18.

\section{REFERENCES}

[1] A. Dobermann and R. Nelson, "Opportunities and solutions for sustainable food production," in Background Paper for the High-Level Panel of Eminent Persons on the Post-2015 Development Agenda, vol. 15 , pp. 25, January 2013.

[2] Food and Agriculture Organization of the United Nations, Towards the Future we want. End Hunger and Make the Transition to Sustainable Agricultural and Food Systems, Rome, Italy, 2012, pp. 42.

[3] European Commission, Sustainable Agriculture for the Future We Want, 2012, pp. 8.

[4] A. Dobele, "Land Resources use in Latvia," Doctoral Thesis Summary, Latvian University of Agriculture, 2005, pp. 33.

[5] I. Pilvere, "Characteristics of land resources in Latvia," in Economics and Rural Development: Research Papers, vol. 4, no. 1, Lithuania: Akademija, 2008, pp. 29-36.

[6] Republic of Latvia Saeima, Latvian Long-term Sustainable Development Strategy up to Year 2030, 2010, pp. 100.

[7] J. N. Pretty, J. Thompson, and F. Hinchcliffe. (May, 2013). Sustainable agriculture: Impacts on food production and challenges for food security, International Institute for Environment and Development. [Online] Gatekeeper Series No. SA60, pp. 24. Available: http://pubs.iied.org/pdfs/6106IIED.pdf 
[8] H. C. J. Godfray, J. R. Beddington, I. R. Crute et al., "Food security: the challenge of feeding 9 billion people," Science, vol. 327, 2010.

[9] R. Flavell, "Sustainable intensification of food production," New Biotechnology, vol. 27, no. 5, November 2010, pp. 505-516.

[10] T. Garnett and C. Godfray, "Sustainable intensification in agriculture. navigating a course through competing food system priorities," Food Climate Research Network and the Oxford Martin Programme on the Future of Food, University of Oxford, UK, 2012, pp. 51.

[11] M. A. Altieri, "Convergence or divide in the movement for sustainable and just agriculture," in Organic Fertilisation, Soil Quality and Human Health, Sustainable Agriculture Reviews 9, E. Lichtfouse Ed., Springer Science Business Media B.V., 2012, pp. 9.

[12] V. Baumane, "Soil quality assessment of the impact of real property cadastral value," in Proc. International Scientific Conference, Economic Science for Rural Development, no. 25, Jelgava, LLU, 2011 pp. 68-75.

[13] V. Baumane, "Analysis of land using in latvia municipalities rural territory of līgo," in Proc. International Scientific Methodical Conference Baltic Surveying, Tartu, Estonia University of Life Sciences, 2012, pp. 26-33.

[14] A. Lenerts and I. Pilvere, "Role of land resources in the development of the market of renewable energy sources of agricultural origin in Latvia," Economic Science for Rural Development: Proceedings of the International Scientific Conference, Rural Business and Finance, no. 28. Jelgava, LLU, 2012, pp. 73-79.

[15] A. Dobele, I. Pilvere, E. Ozols, and L. Dobele, "Land resources for agricultural production in Latvia," in Proc. WEI International European Academic Conference Proceedings, Zagreb, Croatia, October 14-17, 2012, pp. 162-174.

[16] I. Pilvere, "Potential of utilised agricultural area for bioenergy production: The case of Latvia," in Proc. AASRI Conference on Power and Energy Systems, Procedia 2, 2012, pp. $134-141$.

[17] A.P. Barnes and C. E. Z. Poole, "Applying the concept of sustainable intensification to Scottish Agriculture," in Proc. Contributed Paper Prepared for Presentation at the 86th Annual Conference of the Agricultural Economics Society, University of Warwick, United Kingdom, 16-18 April 2012, pp. 20.

[18] I. Pilvere, A. Dobele, and V. Baumane, Research report: Evaluation of Agricultural Land Use, Efficiency, and Options, 2012, pp. 64.

[19] Republic of Latvia Central Statistics Bureau (CSP), Year 2010 Agricultural Census in Latvia, Statistical Data Compilation, Riga, 2011a, pp. 52-73.

[20] Republic of Latvia Central Statistics Bureau (CSP), Agriculture of Latvia, Statistical Data Compilation, Riga, 2012, pp. 14-22.

[21] Republic of Latvia Central Statistics Bureau (CSP) (May 2013). LSK10-I09. Farm Grouping by For Sale Produced Agricultural Goods in the Share of Statistical Regions (\% from total number of farms), 2011b. [Online]. Available: http://data.csb.gov.lv

[22] Rural Support Service (RSS), Land Register Geographical Information Systems Database as of March 01, 2013, unpublished resource.

[23] State Land Service (SLS), Republic of Latvia Administrative Territories and Territorial Units Land Database as of January 01, 2013, unpublished resource.
[24] Latvia University of Agriculture (LLU), Interim Report about the project Land Economically Effective, Sustainable and Productive Use for Agricultural and Forestry Production as of 31/05/2013, Jelgava, pp. 68.

[25] Eurostat. (April 2013). Land use: Number of farms and areas of different crops by type of farming (2-digit), Ha: Utilised agricultural area for 2007, 2010. [Online]. Available: http://appsso.eurostat.ec.europa.eu/nui/show.do?dataset=ef_oluft\&lan $\mathrm{g}=\mathrm{en}$

[26] Eurostat. (April 2013). Gross value added of the agricultural industry basic and producer prices for 2007-2012, Production value at basic price, million EUR. [Online]. Available: http://epp.eurostat.ec.europa.eu/tgm/table.do?tab=table\&init=1\&plug in $=1$ \&language $=$ en $\&$ pcode $=\operatorname{tag} 00056$

[27] Eurostat. (April 2013). Output of the agricultural industry - basic and producer prices for 2007-2012, million EUR. [Online]. Available: http://epp.eurostat.ec.europa.eu/tgm/table.do?tab=table\&init=1\&lang uage $=$ en $\&$ p ode $=\operatorname{tag} 00102 \&$ plugin $=1$

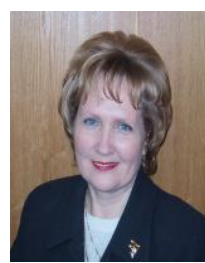

Irina Pilvere received her doctor degree of economics in 2001. And she is now working in Latvia University of Agriculture, Faculty of Economics and Socia Sciences as the Dean and Professor. She has 130 scientific publications and experience in 13 international and 35 national research projects, with scientific focus on following subjects: Agricultural and Rural Development, EU Funds, Effective Use of Resources, Challenges and Trends in Public Administration.

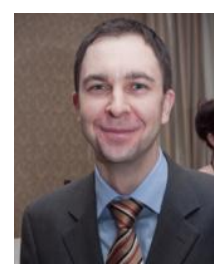

Aleksejs Nipers has earned a doctor's degree in Economics from Riga Technical University, Riga, Latvia, in 2010. His major field of interest during the doctoral studies was modelling of economic processes in a small open economy. He was started his working experience as an Economist at Latvian State Institute of Agrarian Economics in 2004, later continued as a leading researcher at Latvia University of Agriculture and director of RISEBA Institute of Economics and Business in Riga, Latvia. Policy impact evaluation for businesses and public institutions is his current research interest.

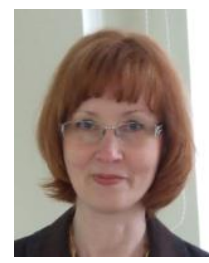

Ilze Upite received her doctor degree of economics in 2010 and she is working in Latvia University of Agriculture, Faculty of Economics and Social Sciences, Department of Business and Management as the assistant professor and as senior specialist in the Ltd "The Latvian Rural Advisory and Training Centre". Research interests: support for agriculture and rural development, competitiveness of enterprises. 